Sebastian Muth

\title{
Linguistic landscapes on the other side of the border: signs, language and the construction of cultural identity in Transnistria
}

\begin{abstract}
In 1992, Transnistria emerged as a de facto independent political entity, not recognized internationally. Russian emerged as a strong marker of a distinct cultural and political identity and as a powerful tool of separation from Moldova. Officially, Transnistria is trilingual in Russian, Ukrainian and Romanian (Moldovan) written in Cyrillic script, yet Russian is the language of choice for most inhabitants. This article presents a linguistic landscape study that sheds light on language use by institutional and private actors in Transnistria, exemplified by signs in the republic’s mainly Russian-speaking capital Tiraspol.
\end{abstract}

Keywords: linguistic landscapes, language policy, border, Transnistria, Moldova

Sebastian Muth: University of Fribourg, Switzerland. E-mail: sebastian.muth@unifr.ch

\section{Borderlands and the post-Soviet sphere}

In recent years scholarly interest in the study of national and transnational boundaries grew and attracted researchers from various academic fields ranging from law, political science and geography to sociology and linguistics. Borders can be material or symbolic, permeable or almost impossible to cross (cf. Omoniyi, this issue). They separate different cultural or political spheres but can also appear as "social and cultural boundaries" that are "instruments through which social distinctions are constructed" (Newman and Paasi 1998: 188). In the wake of the disintegration of the Soviet Union in the early 1990s, studies of the newly emerging Eastern European borderlands surfaced along with works that dealt with the phenomenon more generally (Anderson 1996; Michaelsen and Johnson 1997; Newman and Paasi 1998; Paasi 1999). In the post-Soviet sphere borderlands are not mere geographical lines that divide countries and cultural spheres but instead are often artificial constructs that emerged out of a multilingual empire (Hirsch 2005; Snyder 2003). As such, boundaries are not necessarily static lines but "sets of practices and discourses which spread into the whole of society and 


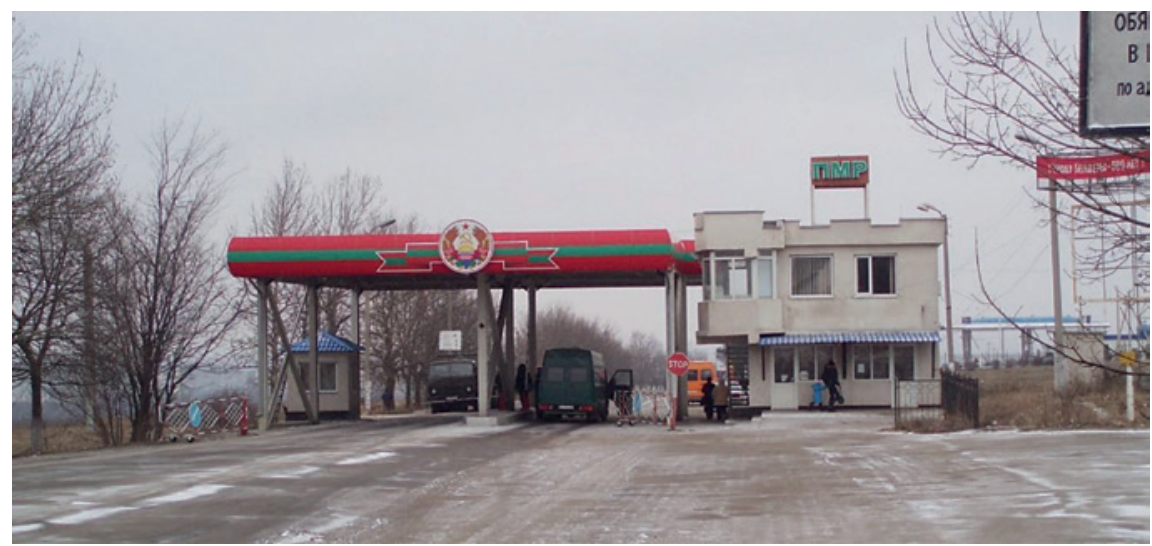

Fig. 1: Border post near Bendery set up by Transnistrian authorities on the main road leading from the Moldovan capital Chișinău to Tiraspol

are not restricted to the border areas" alone (Paasi 1999: 670). Boundaries themselves can have an important function in the symbolic construction of political entities, especially in territories that are not necessarily recognized internationally but function as independent political entities such as Abkhazia or NagornoKarabakh. The self-declared Republic of Transnistria is an example that is often overlooked but that nevertheless is a borderland in itself, located between the Republics of Moldova and Ukraine. No geographical point on the territory is located more than 20 kilometers away from its borders. While "derussification" and "de-sovietization" (Pavlenko 2008b: 282) are characteristic processes in postSoviet contexts and affect neighboring Moldova and Ukraine, Transnistria's Russian borderland-identity is a formative aspect of its cultural and political identity and a bulwark against cultural and political change. From a symbolic perspective this becomes obvious when crossing the border itself (Figure 1).

\subsection{Transnistria: a borderland of cultures and languages}

The self-declared Republic of Transnistria is not recognized internationally as a political entity and has not until now been the focus of sociolinguistic research. It is a product of the breakup of the Soviet Union in the late 1980s and early 1990s, when new nation states emerged on the territory of the former USSR. Officially called Приднестровская Молдавская Республика in Russian or 'Pridnestrovian Moldavian Republic' in English it is an offspring of the former Soviet Republic of Moldova that became independent in 1991. Between the historical Romanian re- 
gion of Bessarabia and Ukraine, situated on the left bank of the Dniester River, Transnistria has ever since been a multi-ethnic and multilingual borderland and a region where "Latinity and Slavdom" meet. It is 5 to 30 kilometers wide, has a size of 4,118 square kilometers - it is more a "strip of land" than a country (King 2000: 178-180).

The roots of the conflict that eventually led to the formation of the breakaway territory can be traced back to the formation of the Soviet Union and the creation of the Moldovan Autonomous Soviet Socialist Republic (MASSR) in 1924 that incorporated present day Transnistria as well as parts of western Ukraine (Roper 2004: 104). Bessarabia on the right bank of the Dniester River was controlled by Romania and developed into an integral part of the country until the onset of World War II. After the war, the Soviet Republic of Moldova was formed that included both Bessarabia and the Transnistrian parts of the MASSR. Efforts to industrialize the Republic and Soviet Moldova resulted in a heavy influx of workers from Russia and Ukraine especially into urban areas. In 1989 approximately 550,000 speakers of Russian lived throughout Moldova (Nygren 2008: 82; Roper 2004: 105). Russian became a language of wider communication and was essential to know in most domains while Romanian spoken in former Bessarabia was changed to Cyrillic script. Soviet scholars highlighted linguistic differences between Romanian and the dialect of Moldovan (Rom. Moldovenesc) and tried to fabricate a distinct Moldovan language to create a distinct Moldovan cultural identity (Pavlenko 2008a: 280; Roper 2004: 105). ${ }^{1}$ Although essentially a home language, "Moldovan" written in Cyrillic script continues to be promoted as a symbolic tool in Transnistria, signaling separateness and to that day "provides one of the most striking recent examples of 'planned' linguistic divergence in language standardization” (Woolhiser 2011: 513).

Within Soviet Moldova, Transnistria enjoyed a special status, as it had "been through the phase of collectivization already before World War II" and its political elite was perceived as being more loyal than the one in Bessarabia (King 2000: 183). When the independence movement in Moldova was formed in the late 1980s, tensions ran high on the left bank of the Dniester as the local political elite feared to lose their influence. Moldovan nationalists campaigned to abandon the Cyrillic script in Romanian, a move that was eventually successful in 1989 when the Latin script was reintroduced (Roper 2005: 509). They also advocated closer ties with Romania in general and many started to view Moldova as a nation belonging to the Romance cultural sphere again. Because of its large share of Russophones, Transnistrian political elites were able to use these fears of

1 For a comprehensive look into the issue of language in Moldova consider Ciscel (2007). 
Romanization and to rally the population against their Bessarabian neighbors. This cumulated in a war in 1992 with over 1,000 dead or wounded, 130,000 internally displaced persons and the effective partition of Moldova (King 2000: 178; Pavlenko 2008a: 62). In the war, Transnistrian forces were supported by units of the Russian Army stationed in the region and later on, the Russian Federation became a staunch advocate of Transnistrian self-determination. Until now the conflict remains frozen and a political solution is out of sight.

\subsection{The politics of power, culture and identity}

In September 2010, Transnistria celebrated two decades of "statehood", a remarkable circumstance given its small size and population. ${ }^{2}$ The main reason for the continuing existence of the territory as a de facto independent political entity lies in ongoing efforts of the Russian Federation to remain politically and culturally present in the region and to ensure political influence in the Republic of Moldova. It considers the region to be not foreign, but "near abroad" and in the last decades has applied the same patterns of geopolitical influence it applied to other disputed regions of the former USSR such as Crimea in Ukraine as well as Abkhazia and Southern Ossetia in Georgia (Popescu and Wilson 2009: 41-43). This includes handing out Russian passports and promoting the Russian language through cultural institutions like Фонд Русский Мир, the Russian World Foundation that is very active in the region. Out of 530,000 inhabitants, around 80,000 to 100,000 hold Russian passports, providing Russian political actors with potential excuses for involvement in the area (Popesco and Wilson 2009: 42).

The construction of a distinct Transnistrian political and cultural identity heavily relies on the ethnic Russian population, and the language they speak is the foremost expression of separateness from Moldovan identity and culture. The demographic makeup of the population is tripartite with equal shares of ethnic Russians, Moldovans and Ukrainians; Russian, Romanian written in Cyrillic script as well as Ukrainian are official languages. Nevertheless, Russian is the language of wider communication throughout the territory (Pavlenko 2008a: 62). In work life, higher education, and the media it is essential to know Russian. Although the Transnistrian regime under former President Igor Smirnov highlighted the multilingual status of the territory, schools attempting to teach Romanian in Latin script are met with obstacles and are even frequently shut down (Dura 2010: 20; Nygren 2008: 95).

2 Transnistria declared independence on 2 September 1990. 
Transnistria is an area where languages, cultures and identities meet and a "testing ground" for the study of the relation between politics and language in a politically contested space. Because of the repressive nature of the regime, research on language attitudes and ethnolinguistic vitality is limited. Yet the study of linguistic landscapes does not involve direct contact with public institutions and local policy makers, but it focuses on the distribution of languages on displays of written language visible to everyone, making such an approach feasible. By studying these public and private displays of "urban public verbal signs" (Spolsky 2009), it is possible to obtain insights into patterns of language use in this European and post-Soviet borderland. Other attempts to study the language situation in the territory are met with suspicion, as (Western) linguists and social scientists are seen as advocates of the Moldovan side who exclusively focus on the spread of the Romanian language and the situation of the Moldovan minority in general. ${ }^{3}$ Certainly there is a pressing need to focus on ethnic Moldovans in Transnistria, as their language is marginalized in the public sphere. Especially in the context of primary and secondary education, Romanian-speakers face obstacles such as the banning of the Latin script. This has led to school closures in the past and the effective disappearance of Romanian in higher education (Roper 2005: 509-510). ${ }^{4}$

\section{Linguistic landscapes in a borderland}

The linguistic landscape may be defined as "any sign or announcement located outside or inside a public institution or a private business in a given geographical location" (Ben-Rafael et al., 2006: 14). From an empirical perspective such an interpretation has the advantage of providing insights on how frequent different languages are visible in the public sphere. Nevertheless, counting signs alone does not say anything about authorship in the linguistic landscape, motivations to display or omit certain languages, or the specific domains in which languages are used (Spolsky 2009: 32). The methodological approach of this study follows

3 Interestingly, the Ukrainian minority is usually not in the focus of works on minorities in Transnistria.

4 The author conducted a study on language attitudes in Transnistria in 2010 among undergraduate university students with the help of the German Academic Exchange Service $D A A D$ at the Transnistrian State University at Tiraspol (PGU) and at its branch in Rybnitsa (RFPGU). Both institutions demanded copies of the questionnaires beforehand and after careful examination, PGU declined while its branch at Rybnitsa allowed the survey to be conducted with most of the questions. 
the paradigm of linguistic landscape analysis established by Landry and Bourhis (1997: 25) that views advertising billboards, shop signs, placards or any other displays of written language as manifestations of the language situation of a particular area. In subsequent studies this approach has been followed among others by Backhaus (2007), Cenoz and Gorter (2006), Huebner (2006), Pavlenko (2010, 2012) as well as Reh (2004). A quantitative study on the distribution of languages on displays of written language is a common approach in linguistic landscape research that has been undertaken by a number of scholars, among others Ben Rafael et al. (2006), Cenoz and Gorter (2006), Huebner (2006) as well as Backhaus (2007). Especially in bi- and multilingual settings and in communities where minority languages are spoken by a significant proportion of the population, linguistic landscape research has the ability to provide data on the representation of these languages in the public sphere and enables us to see if certain languages win out over others, are marginalized, or are used in specific contexts only. In the case of Transnistria, a quantitative perspective in linguistic landscape research has the additional advantage to provide us with an insight into patterns of language use that cannot be studied by using other methods in sociolinguistic research, as large-scale studies on everyday patterns of language use of speakers are not possible because of the restrictive political framework within the territory. While any other method of research that aims at studying the vitality of minority languages such as Romanian or Ukrainian cannot be applied per se, the survey of urban signs is feasible, as it does not raise the suspicion of public authorities and gives us insights, if the official language policy that claims to promote multilingualism and tolerance towards minority languages heralded by the Transnistrian government is reflected in patterns of language use.

However, a numerical count of signs in a select area alone does not necessarily provide generalizable results but instead only gives us a general idea on the distribution of different codes. Following Jaworski and Thurlow (2010: 10-11), studies in linguistic landscapes should focus on "more qualitative, ethnographically oriented studies of language in place ... where the degree of prominence of a language in a particular site is not necessarily the most accurate indicator of the ethnolinguistic vitality of its speakers". In that respect, a discursive perspective that views signs within their particular contexts helps to determine forms, functions and prestige of languages in a presumably multilingual environment such as Transnistria. This perspective will show, if specific languages like Romanian or Ukrainian are used as mere symbols that serve to support the image of a multilingual society or expressions of a genuinely trilingual borderland. Moreover, a discursive and ethnographic perspective also helps to determine whether the use of Russian is a sign of cultural belonging that "transcends physical distance" (Coupland 2007: 122) as a marker of identity for ethnic 
Russians alone, or a genuine tool for wider communication within the whole community.

\subsection{Area of research and methodological perspectives}

The survey focuses on the Transnistrian capital Tiraspol, located halfway between the Moldovan and Ukrainian border (Figure 2). With a population of 140,000 inhabitants Tiraspol is the population center and the economic and transportation hub of the self-declared republic. Tiraspol is not directly located

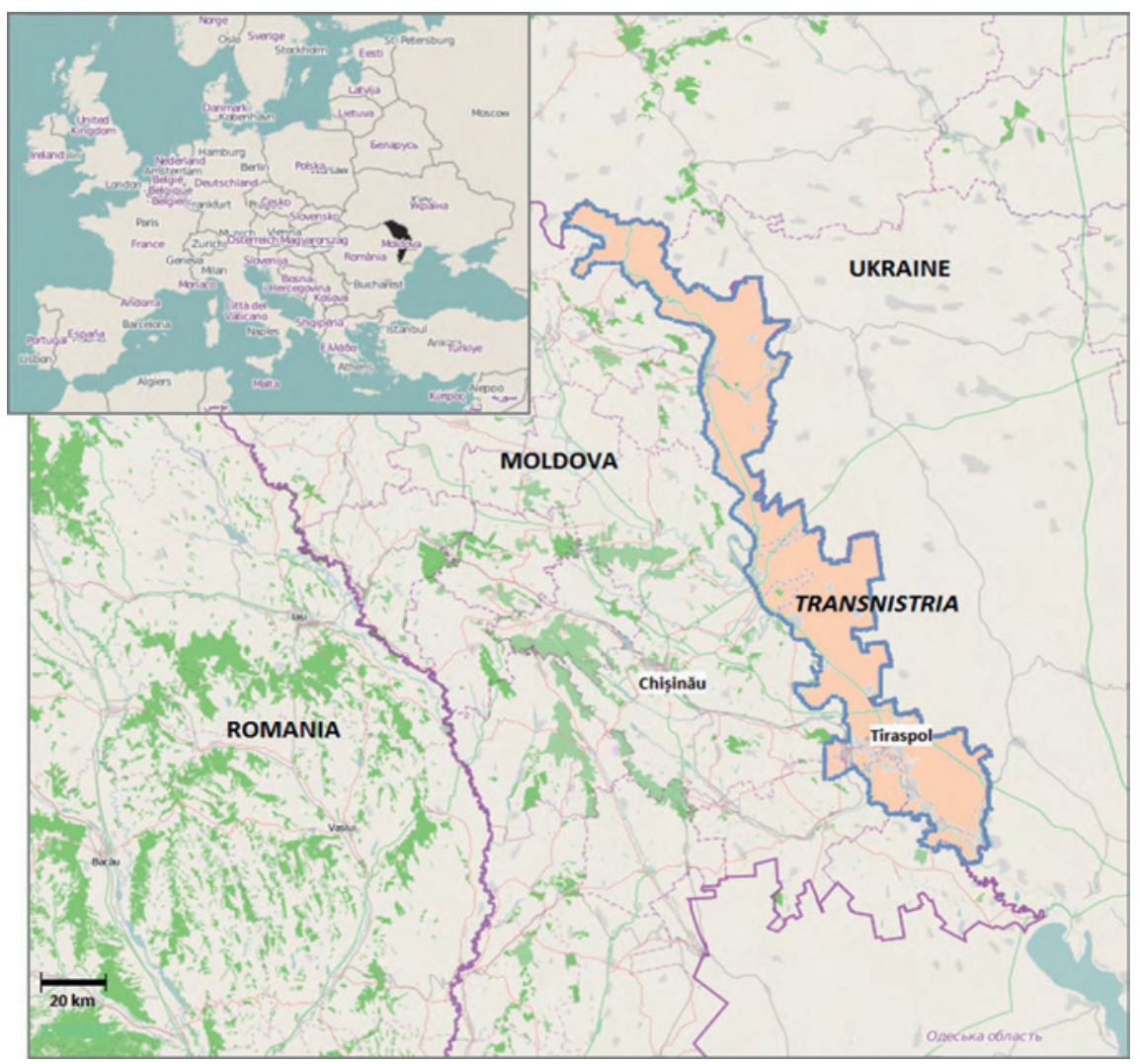

Fig. 2: Location of Moldova within Europe (highlighted in black), and Transnistria between Ukraine and its unrecognized borders with Moldova (scale 1:750,000)

5 Cartographic material was obtained by using OpenStreetMap (www.openstreetmap.org). 
on the demarcation line between Moldova and Transnistria that was drawn after the war between the two political entities in 1992. Nevertheless, the border is located only about 15 kilometers to the west and 10 kilometers to the south. Ukraine borders Tiraspol's city limits to the north; towards the east the border is about 25 kilometers away on the main road that leads to the Ukrainian port city of Odessa.

The city is home to government institutions, numerous state-owned companies and the Transnistrian State University named after Ukrainian poet Taras Shevchenko. The city is considered to be the showcase of the regime and locals in Moldova and Transnistria confirmed that most visitors to the territory only visit Tiraspol's city center. Because of its industrial base, the city, like Transnistria as a whole, witnessed a large influx of workers and professionals from Russia, Ukraine, Kazakhstan and other republics of the USSR during Soviet times (King 2000: 183). This is apparent in the demographic makeup of the city and until today the majority of the population is ethnic Russian. While approximately 40 per cent of the population considers itself Russian, 30 per cent are ethnic Ukrainian while the demographic strength of the local Moldovan population in the city is considerably lower at around 15 per cent. The data on Transnistria presented here has to be met with caution, however, as it cannot be verified independently. Generally, data on ethnicity and language use in Transnistria bears a political dimension not to be underestimated.

For this study, a total of 295 signs were surveyed in Tiraspol on the city's main road, October 25th Street in March 2010. Within a portion of the street ranging from the intersection of October 25th Street and Boulevard Gagarin near the Transnistrian State University in the east towards the Presidential Palace and the seat of the Transnistrian government to the west, all specimens of written language visible to passers-by on both sides of the street were documented. These include top-down signs installed by government bodies, bottom-up signs put up by individuals and private businesses as well as transgressive signs such as graffiti and advertisements painted or sprayed on walls. While this does not necessarily draw a representative sample of written language in the public sphere in the whole of Transnistria, a survey on one of the thoroughfares of Tiraspol encompasses both signs that serve explicitly symbolic purposes as part of political propaganda as well as private signage mainly to advertise goods and services.

\subsection{The representation of language in the public sphere: A quantitative dimension}

As illustrated in Table 1, Russian is by far the dominant language on signs, regardless if those were top-down displays of written language installed by official 
Table 1: Comparison of languages displayed on private (bottom-up) and public (top-down) signage in Tiraspol (October 25th Street)

\begin{tabular}{lc}
\hline Tiraspol & Signs \\
\hline Russian & 221 \\
Russian/English & 55 \\
Russian/Romanian/Ukrainian & 8 \\
Russian/Romanian & 6 \\
Multilingual/other* & 5 \\
& $(\mathrm{n}=295)$ \\
\hline
\end{tabular}

* This category includes signs that displayed Abkhaz, Ossetian, German and French apart from Russian

institutions or government bodies or bottom-up signs put up by private enterprises or individuals. Approximately 75 per cent of signs displayed Russian alone to attract the audience. Almost no sign was surveyed that did not include that language. Unlike in the neighboring Moldovan capital Chișinău where private signage also depicts other languages such as English alone without displaying the demographically strong local languages Romanian and Russian (Muth 2012), in Tiraspol Russian always fulfilled an informative function as an integral part of the linguistic landscape of the city. About 20 per cent of signs included English, usually as catchphrases on shop fronts, advertizing banners or posters aimed at young people. Occasionally, transgressive signs such as graffiti that included English were observed as well but as on private signs in general, English always had a symbolic rather than an informative function. Nevertheless, bottom-up signage did not include one of the other official languages of the territory, Romanian or Ukrainian, leading to the assumption that inhabitants of non-Russian ethnicity are able to navigate the public sphere in Russian. In top-down signage on the other hand, Romanian and Ukrainian were occasionally seen on official signs, but most of the time such signs included additional information like opening hours that were given only in Russian. Streets signs often displayed all three official languages. A look at street signs in side streets and secondary roads, however, revealed that this pattern was the exception rather than the rule and that both Romanian and Ukrainian are symbols rather than actual means of communication.

Yet in order to understand language use on signs in Transnistria and in order to ascribe certain functional domains to the languages used on them, a closer look at signs that represent typical examples of the linguistic landscape is necessary. 


\section{Languages in contest? - A close-up look at public and private signage in Tiraspol}

Public top-down signs are an integral part of the linguistic landscape of urban Transnistria and generally serve two purposes. On the one hand they are installed to inform the public, such as street signs, signs giving directions, or those signaling public offices. On the other hand public top-down signage in Transnistria functions as propaganda to raise the public awareness of the special relations of the territory towards the Russian Federation and the strong political, cultural, and historic ties Transnistria shares with the Russian people. The most elaborate examples of such propaganda can be found in central Tiraspol and along the main roads leading from Moldova into Transnistria.

The first specimen of public signage shown in Figure 3 was surveyed right in the central area of the capital on October 25th Street in front of the Cultural Palace, a popular concert venue built in a Stalinist Empire style. Obviously the message НАША СИЛА В ЕДИНСТВЕ С РОССИЕЙ! 'Our strength lies in the unity with Russia' is written in Russian alone, highlighted by an exclamation mark. On the left-hand corner both the flag and the coat of arms of Transnistria that almost mirror the Soviet symbolism used when Moldova was part of the USSR, are visible. The Russian flag and the coat of arms of the Russian Federation are depicted on the opposite side and right above, the then heads of state of Russia and Trans-

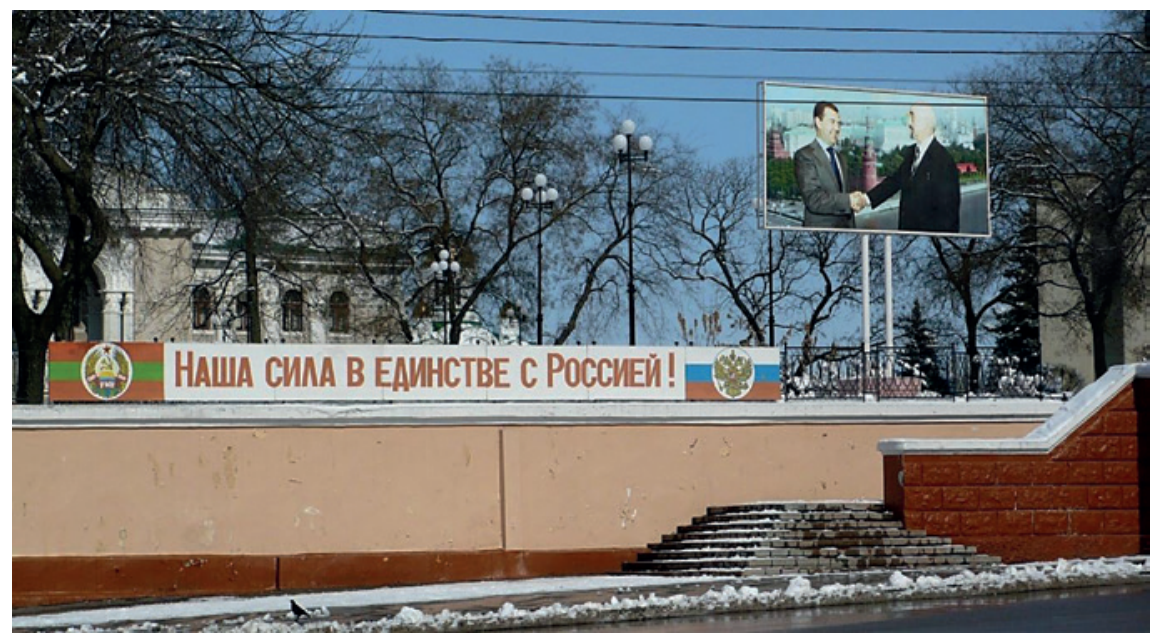

Fig. 3: Top-down Russian-language billboard as political propaganda on October 25th Street in Tiraspol 


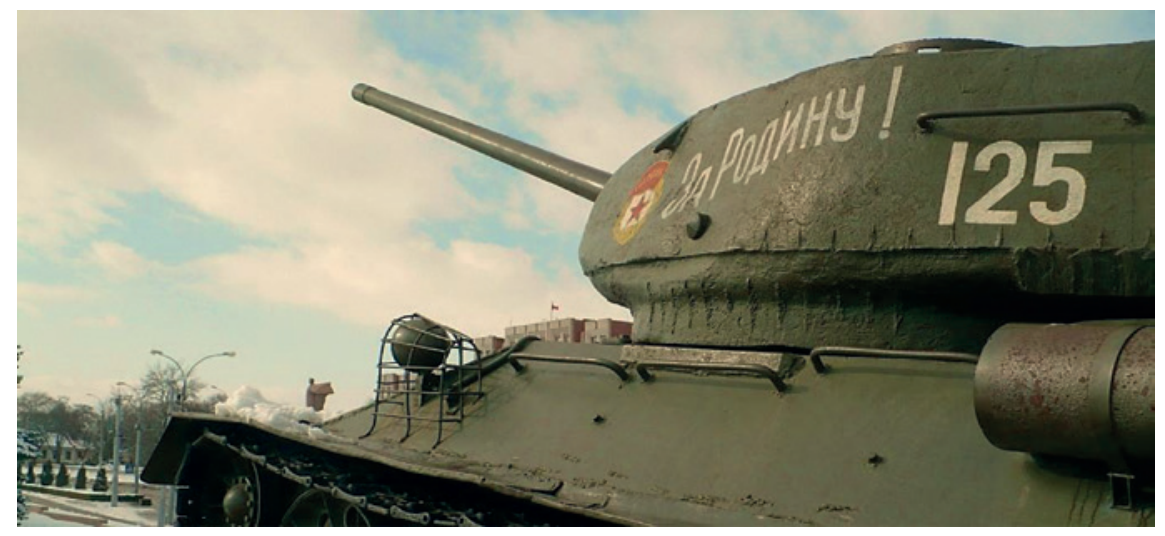

Fig. 4: World War II memorial in close vicinity to the House of Government on October 25th Street

nistria, Dmitry Medvedev and Igor Smirnov shake hands with the Kremlin as a backdrop. The symbolic dimension of the billboard cannot be underestimated as it aims at confirming the unity of Transnistria with Russia and as it depicts long-time President Smirnoff as a reputable leader acknowledged by the Russian president. Furthermore, it declares Transnistria an integral part of the Russian cultural and political sphere.

In close vicinity to the Cultural Palace, the seat of the government of Transnistria and a memorial dedicated to the victims of World War II and Transnistria's own "war of independence" against Moldovan forces in 1992 are located. In this area the cityscape of Tiraspol resembles that of a mid-size Soviet town and the centerpiece of the square opposite to the seat of government is a Soviet Army T-34 tank with its cannon pointed westwards. The tank shown in Figure 4 is famous for its resilience and robustness in the fight of the Soviet Union against invading German forces in World War II and on occasions such as Victory Day on 9 May, political rallies are held at the memorial to commemorate the atrocities committed by German and Romanian forces in Transnistria during the war. From the perspective of linguistic landscape analysis this is one of the rare instances when heavy war machinery actually serves as a unit of analysis and for obvious historic reasons, the Russian exclamation ЗА РОДИНУ! 'for the homeland' as well as the banner of the Soviet Army are shown on the tank.

Close by the memorial the headquarters of the Transnistrian youth organization ПРОРЫВ catch the eye of passers-by (Figure 5). ПРОРЫВ 'breakthrough' is the biggest political youth organization in the territory, officially named Международной Молодежной Корпорации и Народно-демократической 


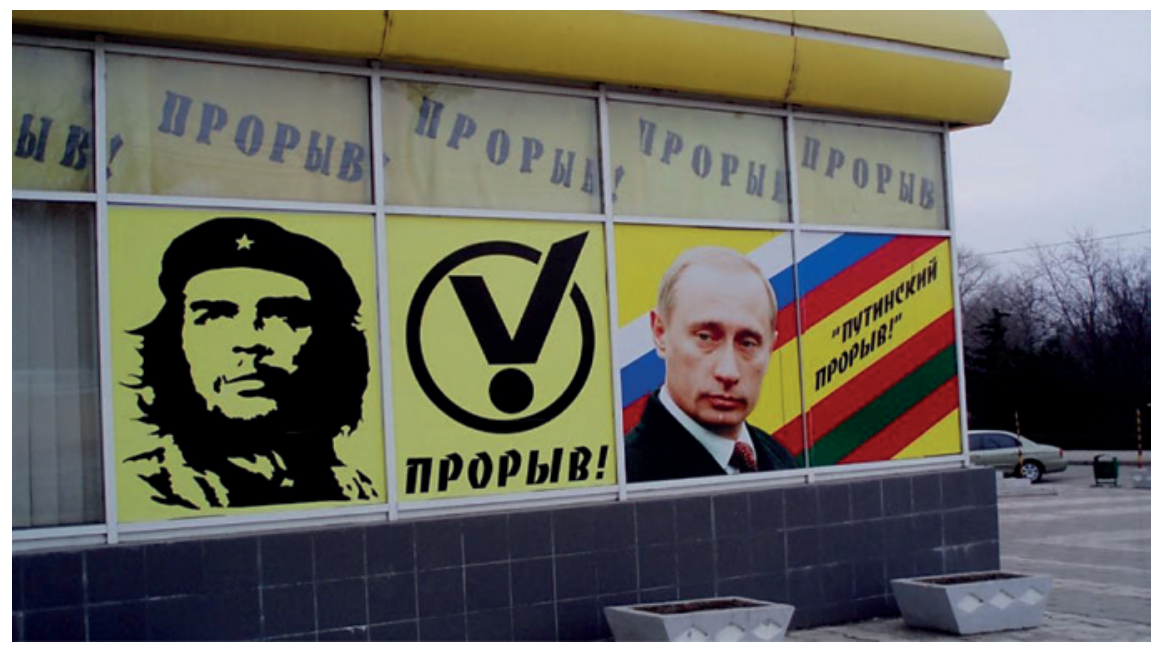

Fig. 5: Headquarters of the Transnistrian youth organization ПРОРЫВ 'breakthrough'

nартии ПРОРЫВ! 'International Youth Corporation and People's Democratic Party Breakthrough!'. It claims to have approximately 1,300 members $^{6}$ and is headed by the influential Transnistrian politician Dmitry Soin and to some extent it is modeled after the Russian youth organization Hamu 'Ours'. ${ }^{7}$ Its policies are staunchly pro-Russian and anti-Moldovan and in the last decade members of ПРОРЫВ became known in the region for their vigorous political activism targeted against international organizations such as the OSCE and the pro-western government in Ukraine under former president Viktor Yushchenko. Its headquarters depict two iconic figures that are seen as role-models for its members the Cuban revolutionary Che Guevara and the current Russian President Vladimir Putin. The choice for an iconic revolutionary figure who appeals to young people in many parts of the world on the one hand and the most influential contemporary Russian politician on the other symbolizes a pretense for both vision and stability. To highlight the organization's special relation to Russia and its proRussian agenda in general, both the flags of the Russian Federation and Transnistria are shown in the background of Vladimir Putin, underlined by the Russian

6 This information was obtained by the author at Tiraspol's headquarters of ПРОРЫВ in March 2010. One has to be cautious about this number.

7 Officially called Молодёжное демократическое антифашистское движение Наши 'Youth Democratic Anti-Fascist Movement Ours', Hawu was established in 2005 and has close relations to the Russian presidential administration. 
catchphrase “ПУТИНСКИЙ ПРОРЫВ!” 'Putin's breakthrough'. Apart from that, the front is dominated by a stylized logo of the organization resembling a victory sign and a repeated depiction of the name of the organization accentuated by an exclamation mark. The existences of political organizations such as ПРОРЫВ that campaign for a cultural and political allegiance with Russia underline the special status of the territory within Moldova and demarcate cultural boundaries with their predominantly Romanian-speaking neighbors. By that, ПРОРЫВ also attempts to create a distinct political and cultural identity among the young that rejects any ties with Moldova and Romania and equates Russian interests with those of the Transnistrian people.

Another example typical of the "political" linguistic landscape of Tiraspol can be found right at the headquarters of the Transnistrian Republican Party Обновление 'Renewal', or 'Renovation', shown in Figure 6 located opposite of the building of the city's Supreme Soviet. As in two of the previous examples it draws on an important figure in Russian politics and depicts Vladimir Putin in his function as the head of Russia's most influential political party, Единая Россия 'United Russia'. It is a monolingual Russian banner that confirms the special relationship of mutual trust and values of both 'United Russia' and 'Renewal' using the Russian noun СОГЛАШЕНИЕ 'agreement' as a caption and - in a rather
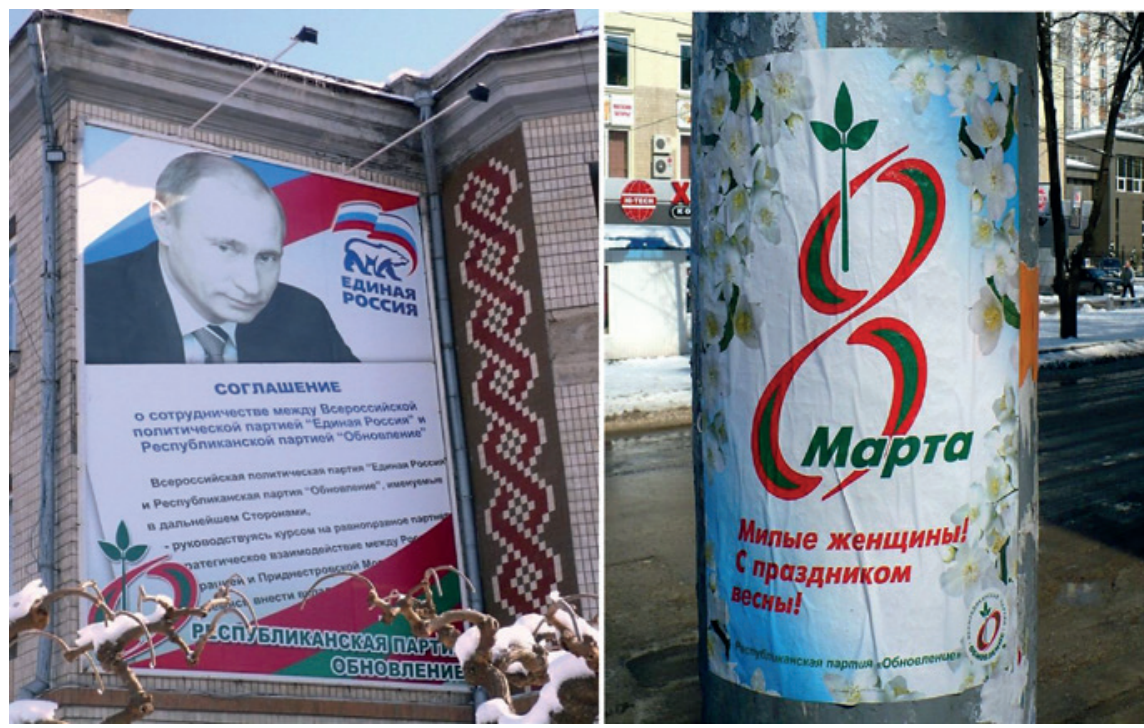

Figs. 6 and 7: Top-down signage by the Transnistrian Republican Party signaling close ties with Russia (6) and celebrating International Women's Day (7) 
elaborate text unusual for advertising banners - the first lines of the partnership agreement are depicted below. Comparable to other examples of political propaganda in the linguistic landscape the banner symbolizes and at the same time reaffirms Transnistria's close ties to Russia. Furthermore it aims at providing a shared feeling of connectedness to reputable forces in the outside world of the otherwise geographically and politically isolated territory. This is confirmed by the picture of then Russian Prime Minister Putin that serves as a symbol guaranteeing the agreement and safeguarding Transnistria's ties with the Russian Federation.

Figure 7 is another example of top-down signage by the biggest party of the territory on the occasion of the International Women's Day, a holiday observed in many countries of the former Soviet Union on 8 March. Beneath the stylized date in the colors of the Transnistrian flag the exclamations Милые женщины! C праздником весны! 'Dear women! Congratulations for the celebration of spring!' are depicted in red letters. Such placards were an integral part of the linguistic landscape of Transnistria in spring 2010, a time right before municipal elections. These are not examples of political propaganda per se, but rather serve as tools to enhance national cohesion and relate to traditions and cultural routines that date back to Soviet times.

Figure 8 also shows examples of displays of written language typical of the cultural and political borderland that exemplify the uncertain status of the territory. Placed at the entrance of an office building they point to the official repre-

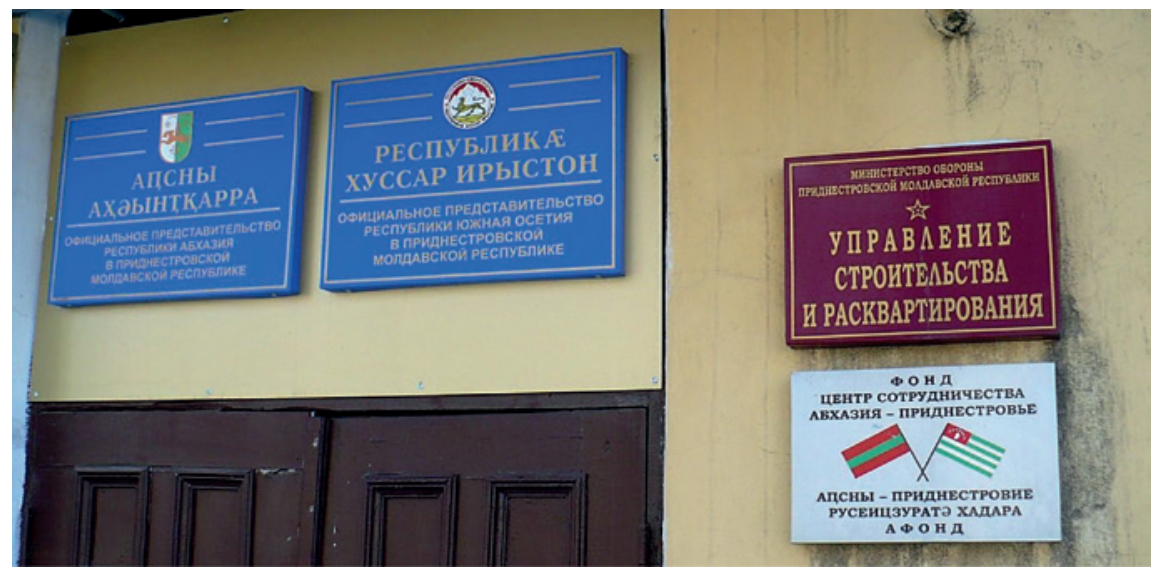

Fig. 8: Public building on October 25th Street with signs of the representations of Abkhazia (left), Southern Ossetia (middle), the Abkhazian-Transnistrian Cultural Foundation (lower right) and a public housing agency (upper right) 
sentations of Abkhazia and Southern Ossetia, both political entities that are not recognized by most of the international community and that are more or less economically dependent on the Russian Federation, sharing the same fate as Transnistria. ${ }^{8}$ The two blue plaques above the door are the actual official signs of the Abkhazian (left) and Southern Ossetian (right) representations in Tiraspol. The names of the territories are written in Abkhaz and Ossetian respectively, and the text beneath, informing passersby on the function of the establishments, is written in Russian. On both it states that these are the "official representations" of Abkhazia as well as Southern Ossetia in the Pridnestrovian Moldovan Republic, giving them a worldly image that appears rather unusual to the spectator in a small provincial city such as Tiraspol. In addition to that, both depict the coat of arms of the territories. Given the secondary status of Abkhaz and Ossetian within these territories itself, the use of both languages can be considered symbolic, whereas Russian is the language that fulfills an informative function. The sign visible in the lower right corner displayed in Russian and Abkhaz stands for АФОНД, a Russian-language acronym for Transnistrian-Abkhazian Friendship Center and depicts the flags of both political entities. The sign right above that is contextually not related to any of the other ones and represents the Transnistrian Public Building and Housing Agency. In font and choice of color it resembles public signage during Soviet times and - contrary to Transnistria's de jure trilingual status - depicts Russian alone.

Close to what one might euphemistically call Tiraspol's "embassy row" the visitor encounters a number of state-owned companies, among them the State Printing House TIPAR, a public entity responsible for the printing of official documents and publications (Figure 9). Similar to many government institutions and state-owned companies it uses trilingual Russian, Romanian and Ukrainian signage, whereas the company's name ТИПАР 'print' is Romanian written in Cyrillic script. In the right and left hand corner of the sign the full name of ТИПАР is given in Romanian and Ukrainian. Despite the official language policy that claims to promote multilingualism in the territory, this was one of the very few examples where Romanian was used, albeit in Cyrillic script. Since 1989 and the onset of the Moldovan independence movement, the Latin script was introduced in Moldova but because of Transnistria's separate status these changes were met

8 Southern Ossetia, Abkhazia, Nagorno-Karabakh and Transnistria are part of the 'Community for Democracy and Rights of Nations' (Rus. Сообщество за демократию и права народов), often referred to as the 'Commonwealth of Unrecognized States'. Only the latter two are not recognized by any other sovereign nation. Both Southern Ossetia and Abkhazia have established diplomatic relations with the Russian Federation, Venezuela, Nicaragua, Nauru, Tuvalu and Vanuatu by 2012. 

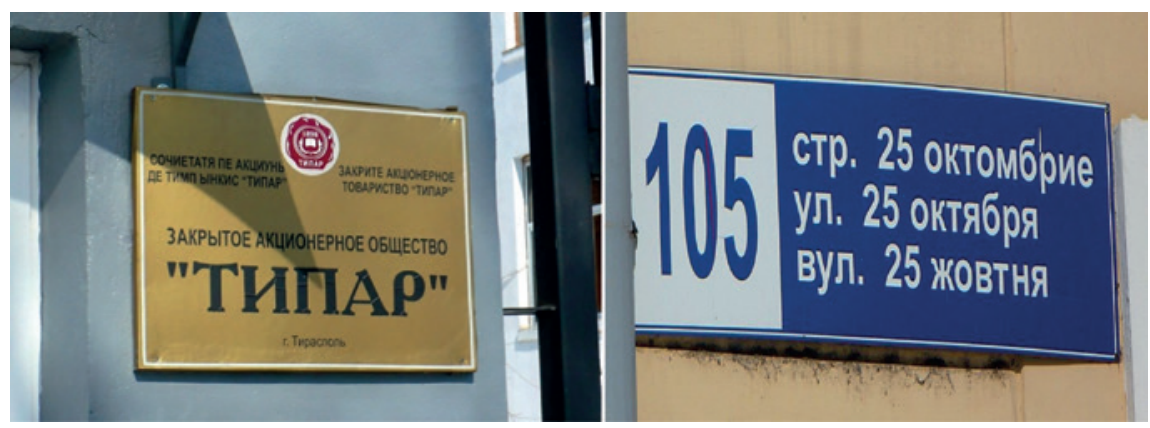

Figs. 9 and 10: Trilingual top-down Romanian, Russian and Ukrainian signage on October 25th Street

with resistance by the authorities in Tiraspol (Roper 2004: 117). Until today the few examples of Romanian signage in the linguistic landscape are depicted in Cyrillic, effectively disadvantaging native speakers and learners of Romanian in Transnistria, as no new teaching materials are available and because this measure hardly makes it possible for them to adapt to language change and variation that takes place in standard Romanian. Instead, in its current form Romanian in Transistrian is a home language at best and local scholars admit that it is in fact a language with very limited functional domains. ${ }^{9}$ In higher education its role is marginalized as well and future teachers of Romanian in the territory are trained to use the same outdated standards and materials that were used during Soviet times. The Ukrainian name of the company depicted in the right corner of the sign also indicates that multilingualism is a mere symbol and a fabricated image and does not mirror actual patterns of language use in society. The Ukrainian part of the sign is actually misspelled, indicating Russian influence. It reads ЗАКРИТЕ АКЦІОНЕРНОЕ ТОВАРИСТВО “ТИПАР” "closed joint stock company Tipar', whereas the standard form in Ukrainian is ЗАКРИТЕ АКЦІОНЕРНЕ ТОВАРИСТВО. This is certainly common on informal signs in the linguistic landscape of any city, but on static signs such a pattern is rather uncommon. Although one might assume that the authorities put a greater emphasis in promoting another Slavic language in Transnistria apart from Russian, Ukrainian is equally marginalized in society and like Romanian it is a home language and not a language one might use in a wide range of functional domains. But also the Roma-

9 Observations made by the author during visits to institutions of higher education in Transnistria in 2010 and 2011. 
nian name of the company in the right-hand corner of the sign reading СОЧИЕТАТЯ ПЕ АКЦИУНЬ ДЕ ТИМП ЫНКИС “ТИПАР” contains a lexical error. Literally it should have meant 'joint stock company of closed type' and it should read ТИП 'type', (tîp in Latin orthography) and not ТИМП (timp) that means 'time' in standard Romanian. Although other surveys of linguistic landscapes have observed variation on static signs as well (Huebner 2006; Backhaus 2007; McCormick and Agnihotri 2009), these usually did not involve top-down signage involving one of the official languages.

Figure 10 represents the last example of public signage. It is a trilingual Romanian, Russian and Ukrainian street sign on October 25th Street. Comparable signs appear in many places in central Tiraspol, but if moving away from the core areas of the city into the suburbs or if one looks at other municipalities throughout Transnistria, this pattern is rather atypical. In most other towns and cities, street names were exclusively displayed in Russian and in case the signs were installed in Soviet times and depicted Romanian in Cyrillic script in addition to Russian, Romanian often had been removed. The reasons for this symbolic multilingualism can be explained by the desire of the authorities to appear to pay tribute to all languages spoken in the territory. Very few visitors actually travel outside the capital and visiting other places in Transnistria is not necessarily encouraged by the authorities.

Private signage installed by individuals and commercial actors alike generally constitutes the majority of displays of written language visible in a community. Comparable to most other urban spaces in the post-Soviet sphere, signs installed by businesses and private individuals dominate the linguistic landscape of downtown Tiraspol. At first sight patterns of publicly displayed written language resemble those of a mid-sized Russian town and subsequently, Russian is the only language that is used to convey information. More generally, language choice on signs used by private actors serves as an indicator of patterns of language use and language awareness in society, and while Russian can be considered to be a lingua franca in some urban parts of Moldova (Ciscel 2007; Muth 2012), the reverse is not true in Transnistria. Instead, advertisements on shop fronts, banners, placards as well as informal expressions such as slogans and notes scribbled on walls were almost exclusively monolingual Russian and manifest the distinctiveness of the territory.

The first example shown in Figure 11 is a typical specimen of a monolingual Russian advertisement that in many ways is unique to Transnistria. It is a small billboard in front of the 'Palace of the Republic' (Дворец Республики) promoting financial services by the Russian 'Gazprombank' (ГАЗПРОМБАНК). While the bank is officially registered as 'Business Invest Bank' (Бизнес Инвест Банк) in the territory, it uses the corporate identity of the Russian parent company. The 


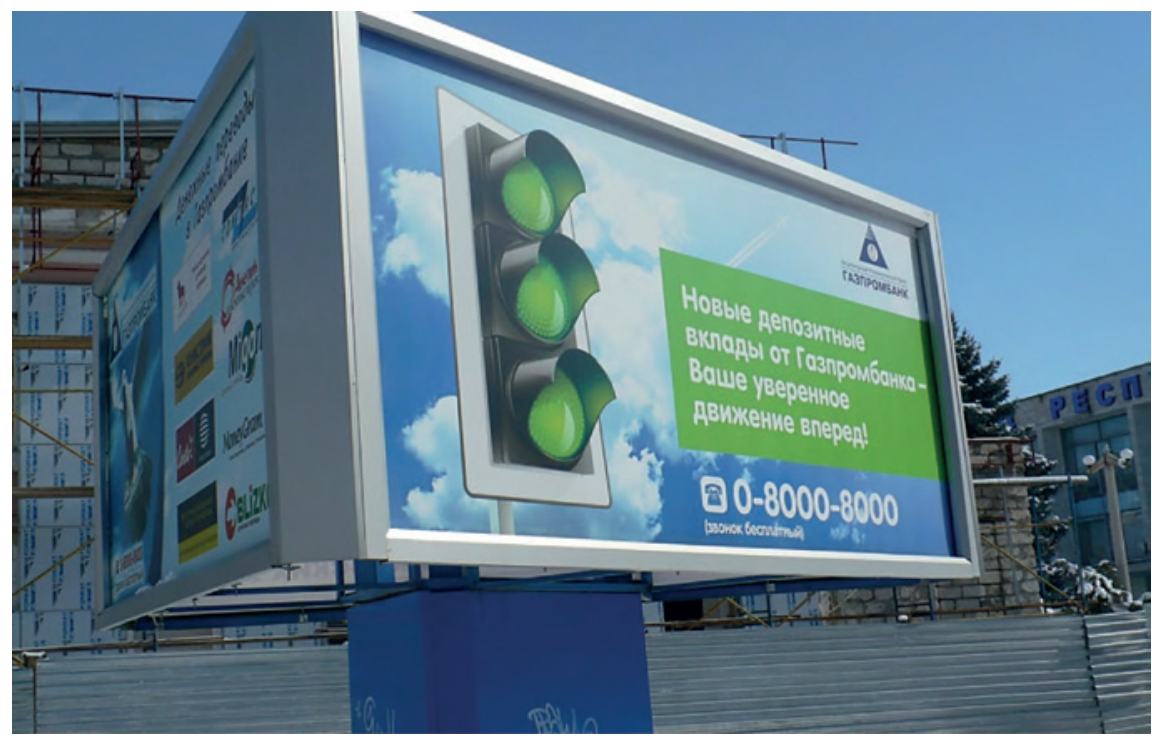

Fig. 11: Billboard advertising financial services of the local branch of Gazprombank

Russian slogan in the center right part of the billboard reads Новые депозитные вклады от Газпромбанка - Ваше уверенное движение вперед! 'New deposits by Gazprombank - Your sure way forward!' and encourages Transnistrians to use its financial services.

Informal bottom-up signs such as posters and notes attached to lampposts, trees or buildings were almost exclusively written in Russian, regardless of which function they fulfill or whom they address. In that respect Figures 12 and 13 represent typical examples of such signage attached to a lamppost. Figure 12 was taken on October 25th Street and is a bilingual Russian-English poster announcing three different parties at 'Equator', a popular nightclub in Tiraspol. One could replace Russian with any other language and the poster would have the same appeal to the young in most communities in the western world. English has a symbolic function and by using the stylized MTV-Icon and the English names of various performing artists such as Dj Gold, Dj Iri \$\$ $\$$ and $D j$ Shooroop, the poster connects to international pop culture. Russian has a limited informative function, and the dates of the events are given in that language.

Another typical informal sign is shown in Figure 13. It is a note written by an individual or a small-scale business offering locals to sell their flat or house. The note reads КУПЛЮ КВАРТИРУ ИЛИ ЧАСТНЫЙ ДОМ В ВАШЕМ РАЙОНЕ 'I will buy an apartment or a private house in your area' in standard Russian. We can 


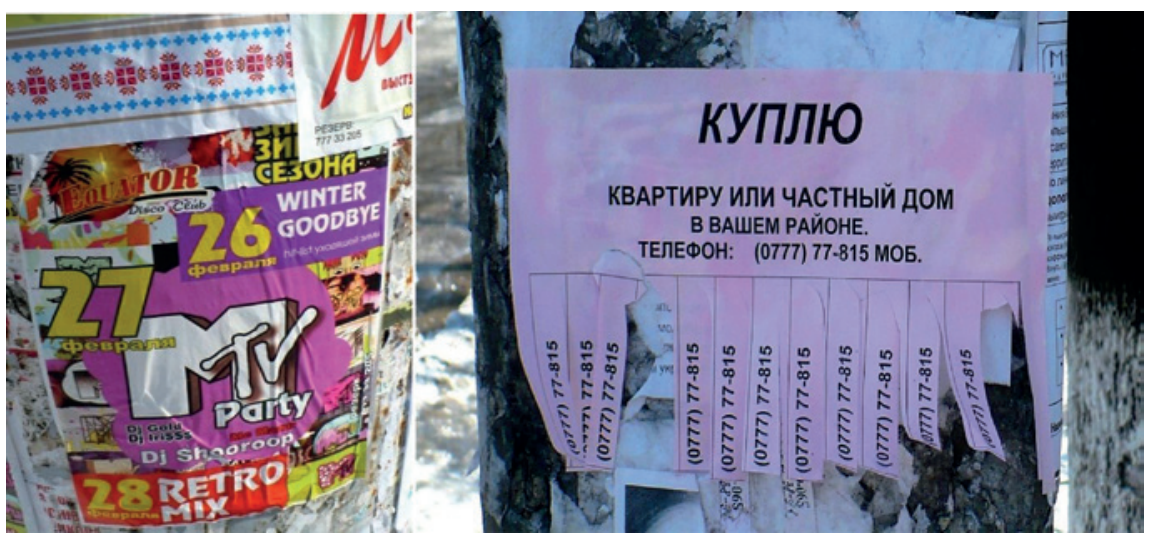

Figs. 12 and 13: Bottom-up placard announcing a concert in Tiraspol (12) and informal note attached to a lamppost offering to buy real estate (13)

assume that the author(s) of the note were not only addressing L1-speakers of Russian, but displaying Russian alone appears to be sufficient within this context. Especially such informal signs where authors do not have to adhere to any regulations or conventions imposed by governing bodies that regulate language use are good indicators of patterns of language use that demographic data cannot provide. ${ }^{10}$ Furthermore, these authors have to economize on space and have to make a conscious choice which language will be understood by most of the addressees. In a multilingual environment such as Transnistria, this leaves the author of informal signage with three options: Russian, Ukrainian and Romanian written in Cyrillic script. In the linguistic landscape of Tiraspol these signs only displayed Russian as a language with informative function. English was occasionally used as well, but never beyond a purely symbolic dimension. The other two languages apparently spoken in the city never appeared, confirming the same patterns that were already observed on official signage. Both Ukrainian and Romanian are confined to a symbolic space constructed by the political elites, literally creating a facade that tries to uphold the self-imposed image of Transnistria as a multiethnic and multilingual territory. Nevertheless, from an outside perspective it is debatable whether the clear dominance of Russian in the linguistic landscape is a point of contempt for Transnistrians of ethnic Moldovan or Ukrainian origin.

10 For an account on language regulations on signs in the Republic of Moldova consider Ciscel (2008). 


\section{Concluding remarks: multilingual borderland or monolingual exclave?}

This article showed that from the point of linguistic landscape research, Transnistria is a monolingual territory where language and cultural identity are used as tools to draw borders and define spheres of political influence. Although linguistic landscape analysis can only provide limited insight into the vitality and the patterns of use of the languages spoken in a given area, it still allows for certain conclusions. On the one hand it became obvious that Romanian, regardless of the script it is written in, is virtually absent from the linguistic landscape. When it is displayed by public actors, it is done so to serve as a mere symbol of multilinguality and tolerance towards another cultural sphere. On the other hand, it also became apparent that Ukrainian is not part of the linguistic landscape either, a fact that is not necessarily surprising as Transnistria has traditionally been inhabited by Russophone Ukrainians. Furthermore, a promotion of Ukrainian would not be in the interest of local political elites, who, regardless of party affiliation, view the territory as a bulwark of Russian culture, identity and language. By international law the territory itself is part of the Republic of Moldova, and the border between the two entities is a dividing line that is not different from borders that separate nation states with different languages, different political histories and cultural backgrounds. The prominent status of Russian as the de facto sole language of Transnistria has been confirmed by other scholars (Ciscel 2007, 2008; Pavlenko 2008a: 62), but if we consider the geopolitical position of the territory, the dominance and ongoing promotion of Russian by local and outside (Russian) elites is more than just an expression of demographic or institutional strength of the language. Within the politically contested space of Transnistria, the clear preference for Russian as a code of communication by public and private actors on signs conveys that is outward-oriented and not only an expression of local language policy measures. It can be considered as a reaction to the ongoing efforts of derussification in many parts of the former Soviet realm, especially in neighboring Moldova and Ukraine. In that respect, the borders of the territory serve not only as lines demarcating political spheres and defining Transnistria as an "independent" political entity, but rather draw a line that defines where de-Sovietization and derussification in the region might come to an end.

Acknowledgments: An earlier version of this research was presented at the CIBER Language and Linguistics Guest Lecture Series at Temple University, Philadelphia, PA. I want to thank Aneta Pavlenko and Elvis Wagner for their valuable comments. Any errors are of course my own. 


\section{References}

Anderson, Malcolm. 1996. Frontiers: Territory and state formation in the modern world. Cambridge: Polity Press.

Backhaus, Peter. 2007. Linguistic landscapes - A comparative study of urban multilingualism in Tokyo. Clevedon: Multilingual Matters.

Ben-Rafael, Eliezer, Elana Shohamy, Muhammad H. Amara \& Nira Trumper-Hecht. 2006. Linguistic landscape as symbolic construction of the public space: The case of Israel. In Durk Gorter (ed.), Linguistic landscape: A new approach to multilingualism, 7-30. Clevedon: Multilingual Matters.

Cenoz, Jasone \& Durk Gorter. 2006. Linguistic landscape and minority languages. In Durk Gorter (ed.), Linguistic landscape: A new approach to multilingualism, 67-80. Clevedon: Multilingual Matters.

Ciscel, Matthew H. 2007. The language of the Moldovans. Lanham: Lexington Books.

Ciscel, Matthew H. 2008. Uneasy compromise: Language and education in Moldova. In Aneta Pavlenko (ed.), Multilingualism in post-Soviet countries, 99-121. Clevedon: Multilingual Matters.

Coupland, Nikolas. 2007. Style: Language variation and identity. Cambridge: Cambridge University Press.

Dura, George. 2010. The EU and Moldova's third sector: Partners in solving the Transnistria conflict? (Microcon Policy Working Paper 14). Brighton: Microcon.

Hirsch, Francine. 2005. Empire of nations: Ethnographic knowledge and the making of the Soviet Union. Ithaca: Cornell University Press.

Huebner, Thom. 2006. Bangkok's linguistic landscapes: Environmental print, codemixing and language change. In Durk Gorter (ed.), Linguistic landscape: A new approach to multilingualism, 31-51. Clevedon: Multilingual Matters.

Jaworski, Adam \& Crispin Thurlow. 2010. Introducing semiotic landscapes. In Adam Jaworski \& Crispin Thurlow (eds.), Semiotic landscapes, 1-37. London \& New York: Continuum.

King, Charles. 2000. The Romanians: Romania, Russia, and the politics of culture. Stanford: Stanford University Press.

Landry, Rodrigue \& Richard Y. Bourhis. 1997. Linguistic landscape and ethnolinguistic vitality: An empirical study. Journal of Language and Social Psychology 6. 23-49.

McCormick, Kay \& Rama Kant Agnihotri. 2009. Forms and functions of English in multilingual signage. English Today 25(3). 11-17.

Michaelsen, Scott \& David Johnson (eds.). 1997. Border theory: The limits of cultural politics. Minneapolis: University of Minnesota Press.

Muth, Sebastian. 2012. The linguistic landscapes of Chișinău and Vilnius - LL and the representation of minority languages in two post-Soviet capitals. In Durk Gorter, Heiko F. Marten \& Luk van Mensel (eds.), Minority languages in the linguistic landscape, 204-224. Basingstoke: Palgrave Macmillan.

Newman, David \& Anssi Paasi. 1998. Fences and neighbours in the postmodern world: boundary narratives in political geography. Progress in Human Geography 22(2). 186-207.

Nygren, Bertil. 2008. The rebuilding of Greater Russia. Putin's foreign policy towards the CIS countries. London \& New York: Routledge.

Paasi, Anssi. 1999. Boundaries as social practice and discourse: The Finnish-Russian border. Regional Studies 33(7). 669-680. 
Pavlenko, Aneta. 2008a. Russian in post-Soviet countries. Russian Linguistics 32. 59-80.

Pavlenko, Aneta. 2008b. Multilingualism in post-Soviet countries: Language revival, language removal, and sociolinguistic theory. The International Journal of Bilingual Education and Bilingualism 11(3/4). 275-314.

Pavlenko, Aneta. 2010. Linguistic landscape of Kyiv, Ukraine: A diachronic study. In Elana Shohamy, Eliezer Ben-Rafael \& Monica Barni (eds.), Linguistic landscape in the city, 133-154. Clevedon: Multilingual Matters.

Pavlenko, Aneta. 2012. Transgression as the norm: Russian in linguistic Landscapes of Kyiv, Ukraine. In Durk Gorter, Heiko F. Marten \& Luk van Mensel (eds.), Minority languages in the linguistic landscape, 36-56. Basingstoke: Palgrave Macmillan.

Popescu, Nicu \& Andrew Wilson. 2009. The limits of enlargement-lite: European and Russian power in the troubled neighbourhood. London: European Council on Foreign Relations.

Reh, Mechthild. 2004. Multilingual writing: a reader-oriented typology - with examples from Lira Municipality (Uganda). International Journal of the Sociology of Language 170. 1-41.

Roper, Steven D. 2004. From frozen conflict to frozen agreement. The unrecognized state of Transnistria. In Tozun Bahcheli, Barry Bartmann \& Henry Srebrnik (eds.), De facto States. The quest for sovereignty, 102-117. London \& New York: Routledge.

Roper, Steven D. 2005. The politicization of education: Identity formation in Moldova and Transnistria. Communist and Post-Communist Studies 38. 501-514.

Snyder, Timothy. 2003. The reconstruction of nations: Poland, Ukraine, Lithuania, Belarus, 1569-1999. New Haven: Yale University Press.

Spolsky, Bernard. 2009. Prolegomena to a sociolinguistic theory of public signage. In Elana Shohamy \& Durk Gorter (eds.), Linguistic landscapes: Expanding the scenery, 25-39. London \& New York: Routledge.

Woolhiser, Curt F. 2011. Border effects in European dialect continua: Dialect maintenance and change. In Berndt Kortmann \& Johan van der Auwera (eds.), Field of linguistics: Europe. 501-523. Berlin \& New York: Mouton de Gruyter. 